\title{
Bioethanol Production from Iles-Iles (Amorphopallus campanulatus) Flour by Fermentation using Zymomonas mobilis
}

\author{
Kusmiyatia ${ }^{*}$, H. Hadiyantob, and Indah Kusumadewi ${ }^{\mathrm{a}}$ \\ a Renewable Energy Research Centre (Pusat Studi Energi Alternatif), \\ Chemical Engineering Department, Faculty of Engineering, Universitas Muhamadiyah Surakarta \\ Jl. A. Yani Tromol Pos 1 Pabelan Kartasura, INDONESIA \\ ${ }^{b}$ Chemical Engineering Department, Faculty of Engineering, Diponegoro University \\ Jl. Prof. Soedarto, SH-Tembalang, Semarang 50239, INDONESIA
}

\begin{abstract}
Due to the depletion of fossil oil sources, Indonesia attempts to search new source of bioenergy including bioethanol. One of this sources is Iles-iles tubers (Amorphophallus campanulatus), which is abundantly available in Java Indonesia. The carbohydrate content in Iles-Iles tuber flour was $77 \%$ and it can be converted to ethanol by three consecutive steps methods consist of liquefaction-saccharification using $\alpha$ and $\beta$-amylase, respectively and then followed by fermentation by using $Z$. mobilis. The objective of this research was to convert the Iles-iles flour to bioethanol by fermentation process with Z.mobilis. The ethanol production process was studied at various starch concentration $15-30 \% \mathrm{~g} / \mathrm{L}, \mathrm{Z}$. mobilis concentration $(10-40 \%)$ and $\mathrm{pH}$ fermentation of (4-6). The result showed that the yield of bioethanol (10.33\%) was the highest at $25 \%$ starch concentration and $25 \%$ of Z.mobilis concentration. The optimum conditions was found at $4.5,30^{\circ} \mathrm{C}, 10 \%, 120 \mathrm{~h}$ for $\mathrm{pH}$, temperature, $Z$. mobilis concentration and fermentation time, respectively at which ACT tuber flour produced a maximum ethanol of $10.33 \% \mathrm{v} / \mathrm{v}$.
\end{abstract}

Keywords: alternative energy, bioethanol, ACT tuber, conventional, Zymomonas mobilis

Article History: Received November $12^{\text {nd }} 2015$; Received in revised form January $25^{\text {th }} 2016$; Accepted January 29 th $^{\text {th }}$ 2016; Available online How to Cite This Article: Kusmiyati , Hadiyanto,H and Kusumadewi, I (2016). Bioethanol Production from Iles-Iles (Amorphopallus campanulatus) Flour by Fermentation using Zymomonas mobilis. Int. Journal of Renewable Energy Development, 9(1), 9-14 http://dx.doi.org/10.14710/ijred.5.1.9-14

\section{Introduction}

The issues of fossil oil depletion have triggered Indonesia to search new renewable energy sources. Moreover, that issue is also stimulated by the increase of price of fossil fuels and the need to protect the planet from the climatic changes caused by the emission of greenhouse gases from burning them (Polycarpou, 2009; Aggarwal, 2007). Developments of new bioenergy such as bioethanol as alternative energy become a very paramount need.

Bioethanol (ethyl alcohol, grain alcohol, CH3$\mathrm{CH} 2-\mathrm{OH}$ ) is a liquid biofuel which can be produced from several different biomass feedstock and conversion technologies through fermentation using microorganism (Balat et al., 2008). Bioethanol can be produced from various natural resources such as molasses (drops), starchy and lignocellulosic materials (Suresh, et al., 1999). There are various feedstocks of ethanol from starchy materials such as cassava, corn, sorghum grain, wheat, barley; from sugar plants such as sugarcane, sugar beet, sweet sorghum; from lignocellulosic materials such as wood and plant stems. Bioethanol has a higher octane number, broader flammability limits, higher flame speeds and higher heats of vaporization than gasoline. These properties allow for a higher compression ratio, shorter burn time and leaner burn engine, which lead to theoretical efficiency advantages over gasoline in an internal combustion engine (Balat, 2011). Disadvantages of bioethanol include its lower energy density than gasoline $(<60 \%)$, its corrosiveness, low flame luminosity, lower vapor pressure, miscibility with water, and toxicity to ecosystems (Mac Lean \& Lave, 2003).

In the last few decades, molasses has been considered as the main source of bioethanol production.

"Corresponding Author:

Email: kusmiyati@ums.ac.id 
Citation: Kusmiyati, Hadiyanto,H and Kusumadewi, I (2016). Bioethanol Production from lles-lles (Amorphopallus campanulatus) Flour by Fermentation using Zymomonas mobilis. Int. Journal of Renewable Energy Development, 5(1),9-14, http://dx.doi.org/10.14710/ijred.5.1.9-14

$\mathrm{P}$ a g e 10

However, the scarcity molasses as a raw material of bioethanol have need of new alternative raw material. The high demand of molasses for bioethanol as well as for animal feed and food additive industry has led to the increase of the price of molasses continuing to rise (Ferreira et al., 2009). Although ethanol is mostly produced from molasses, however it is also produced from corn. Corn is used to produce 13 billion gallons of ethanol in the U.S. Starch containing in corn is a high yield feedstock for ethanol production, hydrolysis and fermentation steps are required to produce ethanol from starch material (Sa'nchez \& Cardona, 2008). Another source for bioethanol is materials containing lignocelluloses despite of its lignin problem. The lignin in cellulosed materials can inhibit the action of the enzyme in breaking down polysaccharides during hydrolysis processes (Samsuri et al. 2007). Nevertheless, the productions of bioethanol from tubers and grains raw materials are still promising due to the abundant availability of starchy materials in Indonesia. One of the sources is Amorphophallus campanulatus or ACT tuber. A. campanulatus tuber (ACT) contains the lowest glucomannan (0-3\%), while the highest of starch (77\% starch), also another components at low concentration such as fiber $(8.5 \%)$, crude protein (14\%), reducing sugar (3-5\%), ash and vitamins (3.4$5.3 \%$ ). The main components of ACT tuber are $71.25 \%$ of starch, $8.54 \%$ of cellulose and $43.30 \%$ of hemicelluloses.

Zymomonas mobilis is a facultative anaerobic bacterium that able to utilize sucrose, glucose and fructose as an energy source, it has a high growth rate and resistance to ethanol concentrations of approximately 16\% (Choi et al., 2008). These bacteria can convert sugars to ethanol and $\mathrm{CO}_{2}$ via the glycolytic "Entner-Doudoroff", where oxygen does not involve in the process of fermentation to avoid inhibition of respiration( Choi et al., 2008). Z. mobilis is a type of bacteria which has an ethanol-tolerant characteristic, therefore it has the higher level of glucose uptake and able to produce ethanol in anaerobic conditions. In addition, these bacteria also have the ability to increase the ethanol purity (Rogers et al., 2007). Furthermore, Choi et al. (2008) showed a great potential of this microorganism for conversion of industrial starch feedstock such as rice, barley, and cassava to produce bioethanol. In addition, Zang \& Feng (2010) revealed that sweet potatoes at substrate concentration of 300$400 \mathrm{~g} / \mathrm{L}$ fermented by using Z. mobilis could produced ethanol yield of 99.1-92.4\%. Some studies showed that Zymomonas mobilis had a low energy efficiency resulting in a higher ethanol yield (up to $97 \%$ of theoretical maximum). Z. mobilis resulted the high ethanol content in the broth as in the case of very high gravity fermentations. Z. mobilis also had been used for ethanol production from dry-milled corn starch, in a system of continuous fluidized bed reactor with immobilized Z. mobilis which showed a high ethanol concentration of $70 \mathrm{~g} / \mathrm{L}$ and a productivity of $23 \mathrm{~g} /(\mathrm{L}$. h). Based on these great potential of $Z$. mobilis, the conversion of ACT flour to bioethanol was expected to be increased. The aim of this study was to utilize ACT flour as raw material for bioethanol production and facilitating Z.mobilis as microorganism in the fermentation. The separated sacharification and fermentation (SSF) method with $\alpha$-amylase in the liquefaction and glucoamylase as enzyme at saccharification was employed to convert the ACT flour to bioethanol.

\section{Materials and Methods}

\subsection{Preparation of Z. mobilis in solid and liquid media}

The bacteria used in this study was Z. mobilis ATCC 29 191, these bacteria were inoculated in solid PGY medium containing $7.5 \mathrm{~g}$ of peptone, $20 \mathrm{~g}$ of glucose, yeast and $4.5 \mathrm{~g}$ of extract, $12 \mathrm{~g}$ of agar, then sterilized in autoclave for 15 minutes.

Z. mobilis was inoculated in a liquid medium containing $20 \mathrm{~g}$ of glucose, $1 \mathrm{~g}$ yeast, $0.5 \mathrm{~g}$ peptone, $0.1 \mathrm{~g}$ $\left(\mathrm{NH}_{4}\right)_{2} \mathrm{SO}_{4}, 0.2 \mathrm{~g} \mathrm{KH}_{2} \mathrm{PO}_{4}, 0.05 \mathrm{~g}$ and $0.05 \mathrm{~g} \mathrm{FeSO}_{4}$ $\mathrm{KH}_{2} \mathrm{SO}_{4} .7 \mathrm{H}_{2} \mathrm{O}$ (Merck) in $100 \mathrm{~mL}$ of distilled water. The medium was sterilized at $121^{\circ} \mathrm{C}$ for $15 \mathrm{~min}$.

\subsection{Preparation of Raw Material}

Fresh ACT tuber was cleaned, stripped and washed to remove the dirty particles. It was cut to small size $( \pm 5 \mathrm{~cm})$, dried under the sun shine until the maximum moisture content was $\pm 10 \%$. The dry ACT tuber was ground to 40 meshes to obtain ACT flour.

\subsection{Hydrolysis}

Hydrolysis enzyme consists of 2 stages, the first stage was liquefaction of ACT flour becomes a complex sugar and the second stage was saccharification. At the first stage, ACT flour was dissolved in water at different flour concentrations of $16,20,25,30,35 \%$ (w/v). The liquefaction was carried out at $\mathrm{pH} 6$ and $1.6 \%$ of $\alpha$ amylase concentration per weight of ACT flour $(v / w)$, temperature at $95-100^{\circ} \mathrm{C}$ for 1 hour. Then, saccharification of liquefied starch was performed at $\mathrm{pH}$ 5 by using $1.6 \%$ of $\beta$-amylase concentration per weight of ACT flour $(\mathrm{v} / \mathrm{w})$ and it was heated at $60^{\circ} \mathrm{C}$ for 4 hours.

\subsection{Fermentation by using Z. mobilis}

Prior to fermentation, the substrates that was placed in erlenmeyers were sterilized in an autoclave $121^{\circ} \mathrm{C}$ for $15 \mathrm{~min}$. The fermentation was carried out using Z. mobilis at temperature of $30^{\circ} \mathrm{C}$ for 120 hours, the samples were withdrawn at $0,24,36,48,72,96$, and $120 \mathrm{~min}$ for remaining glucose and ethanol analysis.

\subsection{Preparation ACT flour at various slurry concentrations \\ ACT flour was dissolved in distilled water at different substrate concentration of $16,20,25,30,35 \%$}


(w/v). The substrate was liquefied, saccharified and followed by fermented by using $10 \%$ of $Z$. mobilis with adding nutrients at 0.2 gram of DAP and 0.4 grams of urea under $\mathrm{pH}$ of 4.5 .

\subsection{Preparation of fermentation slurry at various concentration of Z.mobilis}

Fermentation of substrate slurry with different concentrations of Z. mobilis 10, 20, 30 and $40 \%$ (v/v) were prepared in a substrate slurry with ratio of substrate and water of 1:4. The slurry was subsequently added with $0.2 \mathrm{~g}$ of DAP and $0.4 \mathrm{~g}$ of urea to each sample and it was fermented at $\mathrm{pH} 4.5$.

\subsection{Preparation of fermentation slurry at various $p H$ conditions}

Fermentation was carried out at a substrate concentration ratio of $1: 4$, then it was added with $10 \%$ Z. mobilis, $0.2 \mathrm{~g}$ of DAP and $0.4 \mathrm{~g}$ of urea then fermented at $\mathrm{pH} 4,4.5,5$ and 6.

\subsection{Analysis}

Glucose from hydrolysis was analyzed by the method of double sugar. $10 \mathrm{~g}$ of samples at the stage of saccharification with $\alpha$-amylase and liquefaction with $\beta$ amylase was taken, and then $10 \mathrm{ml}$ of $\mathrm{HCl}$ was added and boiled. After the solutions being cold, a $50 \mathrm{~mL}$ of distill water was added together with 4 drop of indicator phenopthaline and neutralized with $\mathrm{NaOH}$ and diluted. The next step was boiling $5 \mathrm{~mL}$ of Fehling A, 5 $\mathrm{mL}$ of Fehling $\mathrm{B}$ and 3 drops of methylene blue, then titrated with a solution of the sample until the blue color disappeared. Reducing sugar resulted from fermentation was analyzed by the method of Somogy (1945). The analysis starts with mixing a $30 \mathrm{~g}$ of sample with $4 \mathrm{~mL}$ of $10 \mathrm{~N} \mathrm{HCl}$ and boiled, then dissolved in 100 $\mathrm{mL}$ flask. Samples were taken $20 \mathrm{~mL}$ and neutralize using $\mathrm{NaOH}$ and diluted in $100 \mathrm{~mL}$ flask. One mL of sample was taken and $10 \mathrm{~mL}$ of copper reagent was added, and then put in a water bath at a temperature of $10^{\circ} \mathrm{C}$, added $5 \mathrm{ml}$ of sulfuric acid, then titrated with $0.005 \mathrm{~N}$ sodium thiosulfate until the color changes to light yellow, add 2 drops of starch indicator and continue titration until the color changes become clear. The reduced sugar was calculated by using Eq. 1 .

Glucose content $(\mathrm{X})=[\mathrm{A} / \mathrm{B}](\mathrm{Y})+[1 / \mathrm{B}]$

Which, $X$ is a glucose content (\%), $\mathrm{A}$ and $\mathrm{B}$ is a reagent factor and $Y$ is volume of titrate $(\mathrm{mL})$

\section{Results and Discussion}

\subsection{Effect of various substrate concentration on the} amount of reducing sugar

Carbohydrate content in ACT tuber was converted into glucose through hydrolysis of the two-step process which consists of liquefaction and saccharification.
Degradation occurs very rapidly and followed by a very rapid decrease in viscosity, whereas the second phase was much slower to form glucose and maltose. Enzyme $\alpha$-amylase was used in starch hydrolysis liquefaction, while enzyme $\beta$-amylase was used in saccharification. $\alpha$ amylase plays a role in breaking the bonds of $\alpha-1,4$ glucoside from amylose and amylopectin, randomly. While $\beta$-amylase plays a role in breaking the bonds of glucoside $(\alpha-1,4$ and $\beta-1,6$ glucoside $)$ which available in the starch, dextrin and polysacharide into glucose..

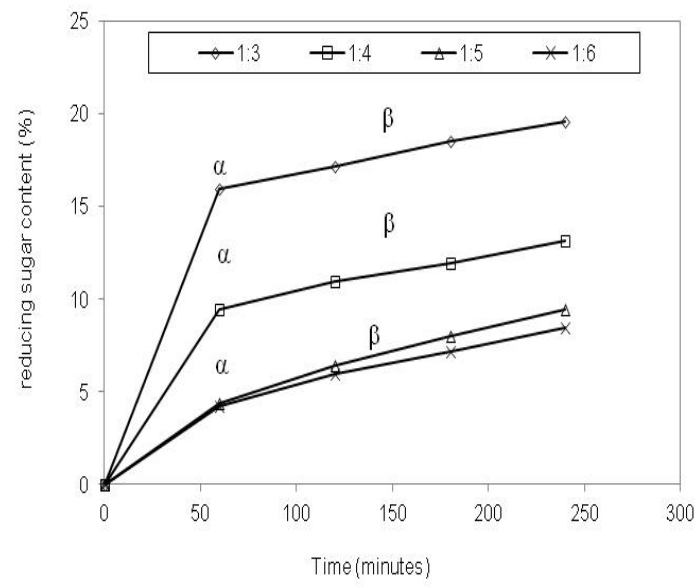

Figure 1 Effect of ACT tuber : water ratio on concentration of reducing sugar. Liquefaction conditions at $\alpha$-amylase $=0.48 \mathrm{~mL} / \mathrm{g}$ dry ACT tuber, $\mathrm{T}=100^{\circ} \mathrm{C}, \mathrm{t}=1 \mathrm{~h}, \mathrm{pH} 6$ and Saccharification conditions at $\beta$ amylase $=0.48 \mathrm{~mL} / \mathrm{g}$ dry ACT tuber, $\mathrm{T}=60^{\circ} \mathrm{C}, \mathrm{t}=3 \mathrm{~h}, \mathrm{pH} 5$ were used

Figure 1 shows that the highest reducing sugar content was achieved at the ACT tuber: water ratio of $1: 3$, which resulted reducing sugar of $15.94 \%$ at one hour of liquefaction and $19.54 \%$ sugar at $\beta$-amylase at 4 hour saccharification. With increasing saccharification time reducing sugar was increased. This result was due to the more active side of the bound enzyme on the substrate that caused more glucose was formed. Substrates with a ratio of $1: 3$ having a minimum water content, therefore glucose was slightly dissolved in water, the more water content in the reactants would decreased of reducing sugar content. This fact was corresponded to the results shown in the concentrations of ACT tuber : water with ratio of 1:4, $1: 5$ and $1: 6$,which indicated the decreased in the result of saccharification of $13.13 \%, 9.45 \%$ and $8.45 \%$, respectively. The result was in accordance with the study reported by Rani et al. (2010) which carried out bioethanol production from slurry of potato flour with solid : liquid ratio of $1: 4$. The potato tubers (Solanum tuberosum) flour was prepared by cooking and drying at $70^{\circ} \mathrm{C}$ prior to hydrolisate. The slurry of potato flour hydrolisate was then liquefied by using $\alpha$-amylase at $80^{\circ} \mathrm{C}$ for $30 \mathrm{~min}$ and followed by saccharification using with glucoamylase at $60^{\circ} \mathrm{C}$ for $2 \mathrm{~h}$ which generated $15.2 \%$ total reducing sugars. Then, fermentation of 
Citation: Kusmiyati, Hadiyanto,H and Kusumadewi, I (2016). Bioethanol Production from lles-lles (Amorphopallus campanulatus) Flour by Fermentation using Zymomonas mobilis. Int. Journal of Renewable Energy Development, 5(1),9-14, http://dx.doi.org/10.14710/ijred.5.1.9-14

$\mathrm{P}$ a g e $\mid 12$

hydrolysate with Saccharomyces cerevisiae HAU-1 at $30^{\circ} \mathrm{C}$ for $48 \mathrm{~h}$ resulted in ethanol production of $56.8 \mathrm{~g} / \mathrm{l}$ ethanol. Previous study conducted by Zang \& Feng (2010) reported that at cassava substrate with concentration of $300 \mathrm{~g} / \mathrm{L}$ produced the highest levels of $17.2 \%$ of reducing sugar content. This result corresponds to results obtained in this study, where the ratio of ACT tuber : water at 1:3 resulted the highest reducing sugar content of $19.54 \%$.

\subsection{Effect of ACT tuber suspension at various concentrations on Ethanol produced}

Figure 2 shows the concentration of ethanol produced from the fermentation process with a variety of flour : water ratio in slurry. Ethanol concentration obtained were $7.4,8.6,6.0$ and $5.22 \%(\mathrm{v} / \mathrm{v})$ for the ratio of flour: water at 1:3,1:4,1:5 and 1:6, respectively which resulted yields of 38.36, 64.32, 63.92 and $43.24 \%$, respectively. The highest ethanol concentration was shown in the ratio of flour : water at 1:4. The excessive solid flour or water content in the slurry resulted the slower reaction which could be shown in slurry at flour : water ratio below and above at 1:4.

In this study, the highest ethanol concentration $(13.13 \% \mathrm{v} / \mathrm{v})$ and yield $(64.42 \%)$ were shown at flour : water ratio of 1:4 with fermentation time of 120 hours. These results were in accordance to previous research conducted by Zhang and Feng (2010) which converted glucose into ethanol by bacteria $Z$. mobilis which obtained ethanol concentration of $12.42 \%$ and yield of $61 \%$ in the presence of $200 \mathrm{~g} / \mathrm{L}$ glucose. The use of $Z$. mobilis CICC10232 for bioethanol production has been evaluated for the fermentation of glucose at different concentration which showed that Z. mobilis CICC10232 could grow well in the glucose fermentation substrate with a concentration of 200-300 g/L glucose. The results indicated that at glucose concentration of 200 , 250 and $300 \mathrm{~g} / \mathrm{L}$ had the different length of lag period in 12,24 and $36 \mathrm{~h}$, respectively. In the presence of 200 $\mathrm{g} / \mathrm{l}$ glucose showed the maximum ethanol yield $(72.5$ $\mathrm{g} / \mathrm{l})$ however the ethanol productivity was reduced in the presence of $250 \mathrm{~g} / \mathrm{L}$ of glucose.

According to Zhang \& Feng (2010), a high ethanol yield was produced from fermentation process at a high concentration of media, but to achieve a high yield it took a long time, therefore it had a low ethanol productivity. This result was in accordance with the experimental results which produced the highest sugar at ratio of flour : water at 1:3 which reached reducing sugar of $19.94 \%$. The sugar concentration at ratio flour : water of 1: 4 was higher than that of 1:3 which produced $13.13 \%$ reducing sugar (as shown in Figure $1)$, however the highest ehanol yield was obtained at ratio flour : water of 1:4 which produced a yield of $64.42 \%$.

The highest ethanol concentration at flour : water ratio 1:3 was due to the high density of fermentation substrat therefore Z. mobilis bacterium could be more active. At the the ratio flour : water of $1: 5$ and $1: 6$, there were excessive water content in the substrate which resulted in a lot of glucose dissolved in water therefore $Z$. mobilis used a little glucose which converted into ethanol.

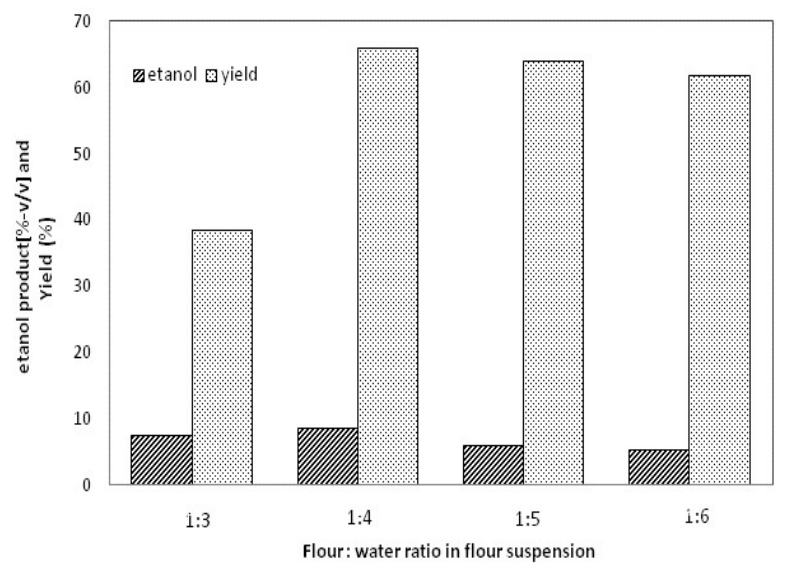

Figure 2 The effect of flour : water ratio in flour slurry on the ethanol concentration $(\% \mathrm{v} / \mathrm{v})$ and ethanol yield. Hydrolisis conditions were constant at $\alpha$-amylase $=0.16 \mathrm{~mL} / 100 \mathrm{~g}$ dry starch, $\mathrm{T}=100^{\circ} \mathrm{C}, \mathrm{t}=1 \mathrm{~h}, \mathrm{pH}$ $6, \beta$-amylase $=0.16 \mathrm{~mL} / 100 \mathrm{~g}$ dry starch, $\mathrm{T}=60^{\circ} \mathrm{C}, \mathrm{t}=3 \mathrm{~h}, \mathrm{pH} 5$. Fermentation condition was constant at $10 \%$ Z. mobilis $\mathrm{pH} 4.5, \mathrm{t}=120$ hours, $\mathrm{T}=28-30^{\circ} \mathrm{C}$.

The effect of starch concentration had been evaluated which reported that the initial dissolved solids concentration exceeds $200 \mathrm{~g} / \mathrm{L}$ implying a higher substrate load had been leading to a higher ethanol concentrations obtained. At a higher starch substrate, the lower amounts of process water was required and energy costs were decreased, however the drawbacks of high starch concentration had effected to a longer fermentation times and sometimes incomplete fermentations which probably caused by product inhibition, high osmotic pressures and inadequate nutrition.

\subsection{Effect of Z. mobilis Concentration on Ethanol Produced}

Figure 3 shows the ethanol concentration $(\%$ $\mathrm{v} / \mathrm{v}$ ) at various $Z$. mobilis concentration of $10-40 \%$ in fermentation substrate which produced ethanol of 8.45$10.16 \%$ for 120 hours fermentation. The highest ethanol content was reached in the concentration of $Z$. mobilis at $30 \%$ which resulted ethanol of $10.16 \%(\%$ $\mathrm{v} / \mathrm{v})$.

The increment of ethanol concentration was in accordance with decreased in reducing sugar concentration, this was indicated that the consumption of sugar by $Z$. mobilis during substrate fermentation process. The rapid decreased in sugar fermentation occurred at 72 to 96 hours, from 3.37 to $0.19 \%$, this condition was accordance with the increasing of ethanol content from 1.86 to $8.21 \%$. This indicated that $Z$. mobilis had a lag phase of 72 hours, the phase that 
bacteria almost stopped growing and the its cell amount were likely to remain.

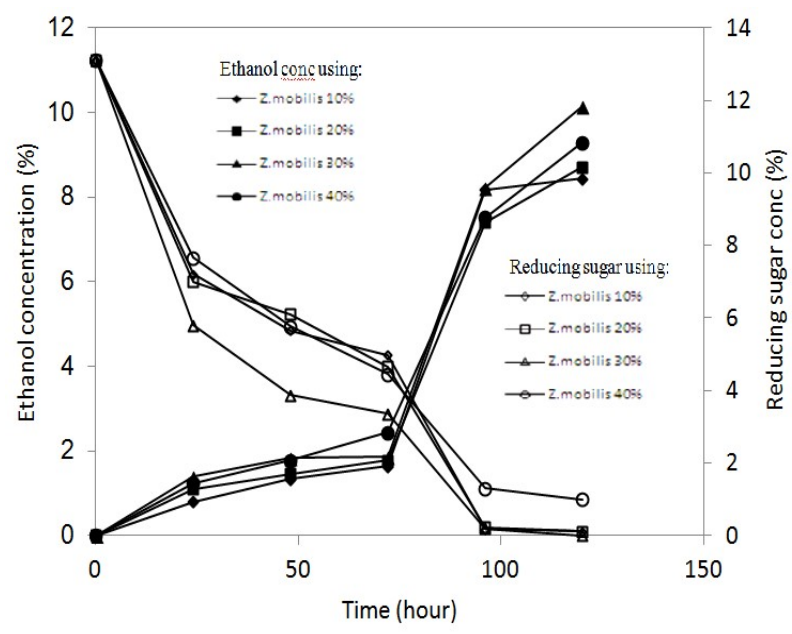

Figure 3 The ethanol concentration and reducing sugar resulted in fermentation on the various concentration of Z.mobilis. Fermentation condition was $\mathrm{T}=28-30^{\circ} \mathrm{C}, \mathrm{t}=120 \mathrm{~h}, \mathrm{pH} 4.5, \mathrm{DAP}=0.2 \mathrm{~g}$, urea=0.4 g.

The lag phase of Z. mobilis shows very slowly compared with the Saccharomyces cereviceae that has 24-hour lag phase. The Log phase on Z. mobilis bacteria was occurred at 96 hours, because of its very rapid growth which characterized by a significant increased in ethanol concentration of $8.21 \%$. The reducing sugar concentration from 96 to 120 hours fermentation was decreased slowly from 0.19 to $1.00 \%$, because the most amount of sugar have been consumed by Z. mobilis. After the log phase, an increased the fermentation time led to the declined ethanol concentration due to a decreased in the number of bacteria that caused the amount of nutrients in the substrate decreased which resulted an increased the number of dead cells. This time was called the death phase. Polycarpou (2009) gained highest yield of ethanol at $30 \%$ of $\mathrm{Z}$. mobilis but then it decreased after $40 \%$ Z. mobilis. This result was due to at the concentration of $40 \%$ Z. mobilis, the amount of sugar in the substrate was not completely converted to ethanol, but rather used as a carbon source for cell growth. The lower of ethanol yield from experimental compared to theoretical ethanol yield had been reported by Polycarpou (2009). The tuber called a Asphodelus aestivus $L$ plant had been used for bioethanol production (Polycarpou, 2009). The process consisted of cooking the flour mash at a temperature of $95{ }^{\circ} \mathrm{C}$, combined by liquefaction and saccharification of the starch using enzymes, like alpha-amylase and glucoamylase. The starch content of the tubers resulted maximum bioethanol yield of $83.72 \mathrm{ml} / \mathrm{kg}$ tubers theoretically. However, from the experiments an ethanol yield of $49.52 \mathrm{ml} / \mathrm{kg}$ tubers was obtained. The reduction of ethanol due to the incomplete fermentation of the sugars in the mash during the three day fermentation process. A small part of the sugar was used by the yeast to produce new cells and grow.

The higher concentration of Z. mobilis caused the higher concentration of ethanol produced in fermentation processes. This was due to the highest amount of sugar in substrate media of $Z$. mobilis which contain of $200 \mathrm{~g}$ of glucose, therefore the highest sugar could be converted to ethanol by $Z$. mobilis.

\subsection{Effect of $p H$ in Fermentation toward Ethanol Concentration}

Figure 4 shows the ethanol concentration produced from the fermentation process with a various $\mathrm{pH}$ conditions. Ethanol concentration obtained at $\mathrm{pH} 4$, $4.5,5$ and 6 were $3.77,8.45,7.18$ and $7.65 \%$, respectively at $120 \mathrm{~h}$ fermentation. Ethanol concentration reached a maximum at $\mathrm{pH} 4.5(8.45 \%)$ at 120 hour fermentation. The decrease in reducing sugar concentration was occurred at 72 to 96 hours of 4.98 to $0.12 \%$. At fermentation time from 0 to 72 hours, the ethanol concentration were low which produced 0.81 , 1.33 and $1.64 \%$ at 24,48 and 72 hours, this fact showed that at this time $Z$. mobilis through a lag phase or phase of adaptation. This suggests that Z. mobilis began working t 72 hours.

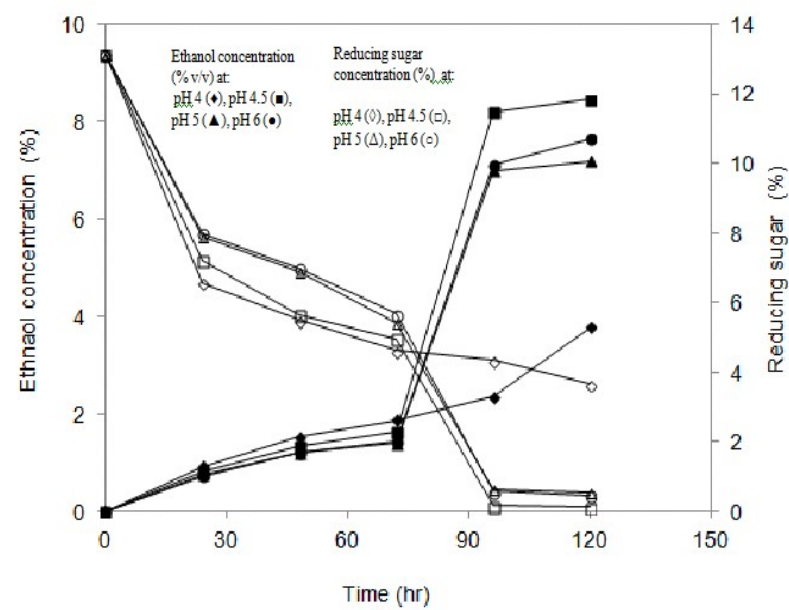

Figure 4 Ethanol and reducing sugar concentration from fermentation at different $\mathrm{pH}$ and constant conditions of $\mathrm{T}=28-30{ }^{\circ} \mathrm{C}$, $\mathrm{t}=120$ hours, $\mathrm{Z}$. mobilis $=10 \%$, DAP=0.2 g, $0.4 \mathrm{~g}$ urea.

Ethanol fermentation at the low $\mathrm{pH}$ of 4.5 using an acid-tolerant mutant of Zymomonas mobilis under non-sterilized condition had been evaluated (Struch et al., 1991). At this low pH, potential contamination of ethanol production was controlled at with and without autoclaving or sterilization. The results revealed that compared with the sterilization process, the same ethanol yield of $73.1 \mathrm{~g} / \mathrm{l}$ was obtained indicated that there were no contamination occurred in the nonsterilized process. At with the autoclaved process, ethanol yield increased from 70.3 to $73.2 \mathrm{~g} / \mathrm{l}$ and residual sugar concentration decreased from 5.3 to 1.3 
Citation: Kusmiyati, Hadiyanto,H and Kusumadewi, I (2016). Bioethanol Production from lles-lles (Amorphopallus campanulatus) Flour by Fermentation using Zymomonas mobilis. Int. Journal of Renewable Energy Development, 5(1),9-14, http://dx.doi.org/10.14710/ijred.5.1.9-14

$\mathrm{P}$ a g e $\mid 14$

$\mathrm{g} / \mathrm{l}$ for $40 \mathrm{~h}$ fermentation. The theoretical yield of ethanol from glucose was $0.488 \mathrm{~g} / \mathrm{g}$ in this ethanol process.

The fermentation process worked well at low $\mathrm{pH}$ to minimize the contamination during the growth of bacteria, the more alkaline conditions led to the rate of fermentation process to convert bacterial to ethanol became slowly. At $\mathrm{pH} 4$ ethanol produced was very low $(3.77 \%)$ at 120 hours, this result was caused by too acidic medium condition which led to $Z$. mobilis, changed its chemical composition and its size therefore the increase in intracellular blocked. At pH 5 and 6 concentration of ethanol were 7.18 and $7.66 \%$, respectively which caused by the high alkalinity condition of the fermentation media, therefore the rate of bacteria in converting sugar to ethanol was slow (Sun \& Cheng, 2002; Suresh et al., 1999). At pH 4.5, the percentage of ethanol concentration was highest therefore for further experiment, $\mathrm{pH} 4.5$ was chosen as the best condition in fermentation process.

\section{Conclusion}

It could be concluded that ACT tuber is an attractive raw material for the production of bioethanol. Based on experimental results, the highest reducing sugar result in hydrolysis was obtained at a ratio of $1: 3$ which reached a sugar concentration of $19.54 \%$ at liquefaction by using $\alpha$-amylase at 1 hour and saccharification by using $\beta$-amylase of 4 hours. Furthermore, the results of saccharified results fermentation of ACT tuber for 120 hours at various flours: water ratio, at the ratio of $1: 4$ yield ethanol concentrations of $64.32 \%(\% \mathrm{v} / \mathrm{v})$. In conclusion, ACT tuber could be a alternative new source of carbohydrate for bioethanol production by using bacteria of $Z$. mobilis.

\section{Acknowledgments}

Our gratitude goes to DP2M, The Directorate of Research, Higher Education and Community Services of Indonesia (DIKTI) for their financial support by year 2011.

\section{References}

Aggarwal, A. K. (2007). Biofuel (alcohol and biodiesel) application as fuels for international combustion engines. Progres in Energy and Combution Sciense , 33., 233-271.

Balat, M. (2011) Production of bioethanol from lignocellulosic materials via the biochemical pathway: A review. Energy Conversion and Management, 52, 858-875.

Balat, M., Balat, H., Oz, C. (2008). Progress in bioethanol processing. Progress in Energy and Combustion Science, 34, 551-573.

Choi, Gi-Wook., Kang, Hyun-Woo., Kim, Young-Ran., Chung, Bong-Woo. (2008) Ethanol production by Zymomonas mobilis CHZ2501 from industrial starch feedstocks. Biotechnology and Bioprocess Engineering, 137,65-771.

Ferreira, S., Duarte, A. P., Ribeiro, H. M. L., Queiroz, J. A., Domingues, F. C. (2009) Response surface optimization of enzymatic hidrolysis of Cytisus Ladanifer and Cytisus Striatus for bioathanol production. Biochemical Engineering Journal, 59, , 618-628.

Mac Lean H.L., Lave, L.B. (2003) Evaluating automobile fuel/propulsion system technologies. Prog Ener Combust Sci, 29, 1-69.

Polycarpou, P. (2009). Bioethanol production from Asphodelus aestivus: A review. Renewable Energy, 34, 2525-2527.

Rani, P., Sharma, S., Garg, F.C., Raj Kushal and Wati Leela ( 2010) Ethanol production from potato flour by Saccharomyces cerevisiae. Indian Journal of Science and Technology, 3 ( 7) , 733736.

Rogers, P. L., Jeon, Y. J., Lee, K. J,, Lawford, H. G. (2007) Zymomonas mobilis for fuel ethanol and higher value products. Adv. Biochem. Eng. Biotechnol, 108, 263-288.

Sa'nchez, O. \& Cardona, C.A. (2008) Trends in biotechnological production of fuel etanol from different feedstocks. Bioresource Technology, 99, 5270-5295

Samsuri, M., Gozan, M., Mardias, R., Baiquni, M., Hermansyah, H., Wijanarko, A., Prasetya, B., Nasikin, M. (2007) Pemanfaatan Selulosa Bagas untuk Produksi Etanol Melalui Sakarifikasi dan Fermentasi Serentak dengan Enzim Xylanase. Makara Teknologi, 11(1), 17-24.

Somogy, M.A. (1945) A new reagent for determination of sugar. J. Biol. Chem.,160, 61-68

Struch T, Neuss B, Bringer-Mayer S, Sahm H. (1991) Osmotic Adjustment of Zymomonas mobilis to Concentrated Glucose Solutions. Application Microbiol, Biotechnol, 34, 518-523.

Sun, Y. \& Cheng, J. (2002) Hidrolysis of lignocellulosic material for ethanol production: a review. Bioresources Technology, 82,1-11.

Suresh, K., Sree, N.K., Rao, L. V.(1999) Utilization of damaged sorghum and rice grains for ethanol production by simultaneous saccharification and fermentation. Bioresource Technology, 68, 301-304.

Zang, K \& Feng, H. (2010) Fermentation potentials of zymomonas mobilis and its application in ethanol production from low-cost raw sweet potato. African Journal of Biotechnology, 9(37), 61226128. 